\title{
The utilization of Noni Fruit (Morinda citrifolia L) as the Ice Cream Ingredient
}

\author{
Anita Juhari ${ }^{1}$, Rodliyati Azrianingsih ${ }^{1}$, Amin Setyo Leksono ${ }^{1}$ \\ Biology Department, Faculty of Mathematics and Natural Sciences, Brawijaya University. Malang ${ }^{1}$
}

Koresponden: Anita Juhari. Email; anitajuhari@ymail.com

\begin{abstract}
ABSTRAK
Penelitiuan ini bertujuan untuk mengetahui persepsi masyarakat terhadap pemanfaatan buah mengkudu dan es krim, mengetahui kandungan nilai gizi dari es krim noni yang dihasilkan, serta mengetahui persepsi masyarakat dan prospek usaha terhadap produk olahan es krim noni. Metode yang dilakukan membuat es krim yang dicampur dengan buah mengkudu, uji kandungan gizi, survey dan wawancara langsung yang dilanjutkan pemasaran produk es krim noni serta dilakukan perhitungan keuntungan yang didapat. Data dianalisis dipresentasikan dalam bentuk grafik serta dilakukan analisis kelayakan usaha. Sebanyak 82,7 \% responden menyukai produk es krim Noni. Es krim noni mempunyai kadar lemak sebesar 6,54 \% lebih rendah dari standart SII sebesar $8 \%$. Kandungan vitamin $C$ dari es krim noni $36.89 \mathrm{mg} / 100 \mathrm{~g}$. Tekstur dan rasa dari produk es krim noni yang paling banyak disukai responden adalah es krim dengan pencampuran $15 \%$ tekstur kasar buah mengkudu (69,9\%). Hasil penjualan es krim noni selama 1 (satu) bulan menunjukkan adanya keuntungan yang diperoleh sebesar Rp 42.200,-. Analisis kelayakan usaha es krim noni sebesar 1,27 $(>1)$. Produksi es krim noni memiliki nilai BEP unit sebesar 65 cup.
\end{abstract}

Kata Kunci : es krim, mengkudu, pengolahan, pemasaran, usaha

\section{ABSTRACT}

The objectives of this research were to determine of the society perception on the use of noni fruit and ice cream, to understand the content of the nutritional value of noni ice cream, and society prospects and perception toward noni ice cream products. The method of this research used a questionnaire survey involving semi structure direct interviews, nutrient content measurement, marketing and beneficial calculation of noni ice cream products. The data were presented in graphical form followed by feasibility analysis. The most of respondent like the Noni ice cream. Noni ice cream consists of $6.54 \%$ fat more than SII standard. Vitamin C in Noni ice cream is $36.89 \mathrm{mg} / 100 \mathrm{~g}$. Popular variant of Noni ice cream is $15 \%$ with chopped noni fruit. Noni ice cream selling for a month resulted profit IDR 42,200. Noni ice cream reasonable to sell because appropriate analysis more than 1 (1.27). BEP product score is 65 cup of ice cream.

Key words business, ice cream, marketing, noni, processing

\section{PENDAHULUAN}

Mengkudu merupakan tanaman tropis asli Indonesia yang merupakan salah satu komoditi bahan alam. Buah mengkudu memiliki kandungan alami yang dapat mengobati beberapa penyakit degeneratif, serta dapat meningkatkan stamina tubuh dengan cara membantu pembentukan protein yang diperlukan oleh tubuh sehingga aman jika dikonsumsi [1]. Akan tetapi, masyarakat cenderung tidak menyukai buah menkudu ini, karena buah ini memiliki aroma dan rasa yang kurang disukai [2]. Suatu upaya yang dilakukan untuk mengurangi ketidaksukaan masyarakat terhadap buah mengkudu adalah dengan cara mencampurkan buah mengkudu dalam es krim, karena es krim merupakan salah satu makanan bernilai gizi tinggi yang disukai oleh masyarakat, sehingga cocok apabila digabungkan dengan buah mengkudu yang memiliki fungsi dalam bidang kesehatan (obat). Pengolahan buah mengkudu dalam es krim ini kemudian disebut dengan es krim noni.

Selama ini produk es krim yang sering dijumpai adalah es krim dengan rasa buah (apel, melon, strawberi, dll). Sedangkan olahan dari buah mengkudu saat ini masih dijumpai dalam bentuk obat, jus, rujak, ramuan yang direbus dan cincau noni. Menurut penelitian 
terdahulu buah mengkudu dapat diolah sebagai campuran gel cincau yang kemudian disebut cincau noni di kota Malang yang mendapat respon baik dari masyarakat [3]. Pengolahan buah mengkudu dalam es krim diperkirakan akan menjadi produk yang disukai masyarakat. Apabila produk yang dihasilkan berkualitas baik maka akan meningkatkan minat konsumen sehingga dapat meningkatkan nilai ekonomi buah mengkudu dan mendukung daya gunanya sebagai tanaman lokal Indonesia. Penelitian ini bertujuan untuk mengetahui persepsi masyarakat terhadap pemanfaatan buah mengkudu dan es krim, cara menghasilkan produk olahan buah mengkudu menjadi es krim, kandungan nilai gizi dari es krim noni yang dihasilkan, serta persepsi masyarakat dan prospek usaha terhadap produk olahan es krim noni.

\section{METODE PENELITIAN}

\section{Waktu dan Tempat.}

Penelitian ini dilaksanakan di kawasan area Malang yang terdiri dari tiga tempat yaitu Kelurahan Sumbersari, Desa Kertoleksono dan Kelurahan M.T Haryono, dan area kampus yang terdiri dari tiga fakultas yang mencakup Fakultas Teknik, MIPA, dan Perikanan, Universitas Brawijaya, Malang.

\section{Responden}

Survei pendahuluan yang dilakukan antara lain perizinan ke Kesbangpol dan Kecamatan yang sudah ditentukan untuk melakukan pemasaran produk es krim noni serta penentuan responden. Selain itu, dilakukan wawancara semi-terstruktur terhadap masyarakat sekitar untuk mendapatkan informasi tentang persepsi masyarakat tentang buah mengkudu, produk olahan es krim noni dan prospek usaha produk es krim noni dilakukan pada 110 penduduk. Responden merupakan perempuan dan laki-laki berusia lebih dari 17 tahun.

\section{Pengolahan Buah Mengkudu dan Es Krim Menjadi Es Krim Noni}

Langkah pertama yang dilakukan adalah membuat ekstrak cair buah mengkudu terlebih dahulu dengan cara buah mengkudu ditimbang sebanyak $500 \mathrm{~g}$ dan dicuci dengan air mengalir. Setelah buah mengkudu bersih dilakukan pengupasan dan dipisahkan dari biji. Irisan buah mengkudu yang didapat dihaluskan dengan menggunakan blender dengan ditambahkan air $50 \mathrm{ml}$, yang kemudian dilakukan penyaringan untuk memperoleh ekstrak cair dari buah mengkudu tersebut dan ditimbang sebanyak $200 \mathrm{~mL}$.

Langkah ke dua dilakukan pencampuran dari gula halus sebanyak $100 \mathrm{~g}$, air $100 \mathrm{~mL}$, susu cair $150 \mathrm{~mL}$, cmc $1 / 2$ sendok teh, serta essence 1 sendok teh dengan menggunakan alat bantuan mixer. Setelah bahan-bahan tersebut tercampur ditambahkan ekstrak cair buah mengkudu $200 \mathrm{ml}$ dan di campur menggunakan mixer.

Langkah ke tiga diakukan pencampuran dari 3 butir kuning telur, wippy cream $200 \mathrm{~g}$, gula halus $100 \mathrm{~g}$ dan air $100 \mathrm{~mL}$ dengan menggunakan alat bantuan mixer sampai mengembang. Setelah campuran tersebut mengembang ditambahkan campuran yang di peroleh dari langah kedua. Adonan dicampur menggunakan mixer sampai halus dan mengembang, kemudian dilakukan penyimpanan dalam lemari es selama 3 jam. Setelah 3 jam penyimpanan, adonan dikeluarkan dan dilakukan pengadukan ulang menggunakan mixer agar dapat memperoleh tekstur yang lembut untuk es krim noni, kemudian didinginkan lagi selama 4 jam.

\section{Uji organoleptik}

Uji organoleptik dilakukan untuk mengetahui tingkat kesukaan atau kelayakan suatu produk agar dapat diterima oleh konsumen. Pengujian ini dilakukan dengan membuat es krim noni dengan 3 perlakuan (tanpa mengkudu, $15 \%$ ekstrak halus dan $15 \%$ ekstrak kasar). Sifat organoleptik yang diujikan pada penelitian ini adalah segi tekstur (kelembutan) dan rasa. Dalam uji ini responden diminta memberikan penilaian berdasarkan tingkat kesukaan terhadap tekstur (kelembutan) dan rasa es krim yang disajikan.

\section{Analisis nilai gizi}

Kandungan gizi dari es krim noni dianalisis yang dilakukan di Laboratorium Pengujian Mutu dan Keamanan Pangan Fakultas Teknologi Pertanian Universitas Brawijaya. Uji yang dilakukan antara lain uji lemak, protein, air, abu, karbohidrat, serta kandungan vitamin $\mathrm{C}$ dari es krim noni.

\section{Pemasaran produk es krim noni}

Penjualan es krim noni dilakukan dengan cara dititipkan pada wilayah yang sudah 
ditentukan selama 1 bulan. Perhitungan laba yang didapat dilakukan penghitungan dengan menggunakan rumus [4]:

$$
\begin{aligned}
& \mathrm{H}=\mathrm{TR}-\mathrm{TC} \\
& \mathrm{T}=\mathrm{P} \times \mathrm{Q}
\end{aligned}
$$

Keterangan:

$$
\begin{aligned}
& \mathrm{H} \quad=\text { Keuntungan } \\
& \mathrm{TR} \quad=\text { total revenue (total pendapatan) } \\
& \mathrm{P} \quad=\text { Harga per unit yang terjual } \\
& \mathrm{Q} \quad=\text { Jumlah per unit yang terjual } \\
& \mathrm{TC} \quad=\text { total cost (total biaya yang } \\
& \text { dikeluarkan) }
\end{aligned}
$$

Keterangan:

$$
{ }^{\mathrm{RC}} \text { ratio }=\frac{T R}{T C}
$$

$\mathrm{RC}$ ratio $=$ Return Cost Ratio

$\mathrm{TR} \quad=$ Total pemasukan

TC = Total biaya yang dikeluarkan

$1>\quad=$ Usaha layak diteruskan

$1 \leq \quad=$ Usahatidak layak diteruskan

Harga pokok tiap satuan ditentukan dengan rumus :

Keterangan:

$$
\text { Harga produk }=\text { HPP }+ \text { Markup }
$$

HPP = Harga pokok penjualan

$$
=\frac{\mathrm{TC}}{\mathrm{Q}}
$$

Mark up = Keuntungan yang diperoleh dari penjualan

Analisis titik pulang pokok (Break Even Point/BEP) adalah suatu teknik analisa untuk mempelajari hubungan antara biaya tetap, biaya variabel, keuntungan dan volume aktivitas. BEP dapat ditentukan dengan pendekatan matematis [5].

$$
\mathrm{BEP} \text { (unit) }=\frac{\text { total biaya tetap }}{\text { total hasil penjualan - total biaya variabel }}
$$

\section{HASIL DAN PEMBAHASAN}

\section{Persepsi Masyarakat terhadap Pemanfaatan Buah Mengkudu dan Es Krim}

Sebanyak 88,2 \% responden mengetahui tentang buah mengkudu, sedangkan yang tidak mengetahuinya sebesar 11,8 \% (Tabel 1). Sebanyak 65,5 \% responden tidak pernah mengonsumsi buah mengkudu. Hal ini dikarenakan menurut pendapat responden buah tersebut memiliki rasa yang langu atau pahit serta masyarakat menganggap buah tersebut hanya dikonsumsi sebagai obat atau jamu untuk mengobati suatu penyakit tertentu. Menurut Waha (2002) buah mengkudu tidak saja cocok dikonsumsi oleh orang sakit, tetapi dapat juga dikonsumsi orang yang berada dalam kondisi sehat termasuk anak - anak, wanita hamil, dan ibu menyusui [6]. Sebanyak $83,4 \%$ responden tidak meyukai aroma dari buah mengkudu karena buah tersebut memiliki aroma kurang sedap atau busuk. Responden yang mengetahui khasiat dari buah mengkudu sebesar $66,7 \%$ dan yang tidak mengetahui khasiatnya sebesar 24,5\% (Tabel 1). Buah mengkudu memiliki kandungan alami yang bermanfaat mengobati beberapa penyakit degeneratif, antara lain: hipertensi, kolestrol, kelebihan kadar gula darah, stroke, dan jantung coroner [1]. Berbeda halnya dengan buah mengkudu, es krim jauh disukai oleh masyarakat. Berdasarkan survei yang telah dilakukan, sebesar $100 \%$ responden menyukai es krim dan mengonsumsinya (Tabel 1). Akan tetapi 46,5\% responden tidak mengetahui tentang kandungan dari es krim yang biasanya konsumsi. Setelah dilakukan survei, sebesar $82,7 \%$ responden menyukai dan tertarik untuk mengonsumsi produk es krim noni. Ketertarikan masyarakat terhadap produk es krim noni adalah memiliki rasa dan aroma yang manis serta mempunyai tekstur yang lembut sehingga responden menganggap produk ini layak untuk dikonsumsi dan diperdagangkan.

\section{Persepsi Masyarakat terhadap Sifat Organoleptik \\ 1. Kelembutan.}

Produk yang paling banyak disukai responden $(69,9 \%)$ adalah es krim dengan pencampuran $15 \%$ tekstur kasar buah mengkudu (Gambar 1). Hal ini dikarenakan es krim tersebut mempunyai teksur yang berbeda dari es krim yang umum dijumpai, yaitu memiliki tektur lembut tetapi di dalamnya terdapat campuran potongan-potongan kecil dari buah mengkudu yang tampaknya lebih disukai oleh responden. Tekstur es krim yang baik adalah halus atau lembut (smooth), tidak keras, dan tampak mengkilap, sedangkan tekstur yang buruk adalah greasy (terasa ada gumpalan lemak), grainy (terasa seperti tepung), snowy (terasa ada serpihan es), gelatin (seperti jelly), dan sandy (berpasir)[7]. 


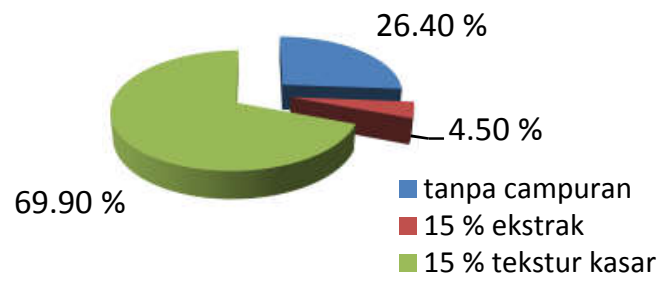

Gambar 1. Persentase responden yang menyukai tekstur produk es krim yang dicampurkan dengan ekstrak buah mengkudu

\section{Rasa}

Sebesar 36,4 \% responden menyukai es krim tanpa campuran buah mengkudu, hanya $4,5 \%$ responden yang menyukai produk es krim dengan pencampuran buah mengkudu cair, sementara itu jumlah responden terbanyak $(54,5 \%)$ menyukai pencampuran tekstur kasar buah mengkudu (Gambar 2). Sebanyak $82,7 \%$ responden menyukai produk es krim Noni.

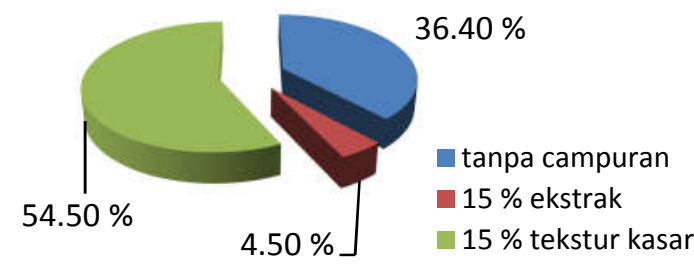

Gambar 2. Persentase responden yang menyukai rasa produk es krim yang dicampurkan dengan ekstrak buah mengkudu

Responden berpendapat bahwa es krim dengan pencampuran $15 \%$ buah mengkudu kasar tersebut memiliki rasa manis serta di dalamnya terdapat campuran potonganpotongan kecil dari buah mengkudu yang terasa kenyal sehingga lebih disukai oleh responden.

\section{Kandungan Gizi Es Krim Mengkudu (Noni)}

Hasil pengujian kandungan nutrisi es krim noni yang didapat dibandingkan dengan syarat mutu es krim menurut SII Nomor 1617 Tahun 1985. Berdasarkan hasil analisis kandungan nutrisi dalam es krim noni diperoleh karbohidrat sebesar 36,23 \% (Tabel 2). Kandungan karbohidrat es krim noni lebih tinggi dibandingkan dengan es krim yang beredar di pasaran (Wall's) yaitu sebesar $4 \%$ (Tabel 6). Kandungan lemak es krim noni sebesar 6,54 \%, menurut standart SII kadar lemak dalam es krim minimal 8,0 \% (Tabel 3). Kandungan lemak dari es krim noni lebih rendah daripada es krim yang beredar di pasaran (Wall's) yaitu sebesar $8 \%$ (Tabel 4). Dengan demikian, es krim ini baik dikonsumsi oleh masyarakat karena mempunyai kandungan lemak yang rendah.

Kandungan vitamin $\mathrm{C}$ dari es krim noni sebesar $36,89 \mathrm{mg} / 100 \mathrm{~g}$. Hal ini dapat disebabkan karena dalam proses pembuatan es krim noni dilakukan proses pendinginan yang tidak akan merusak struktur dari vitamin $\mathrm{C}$ yang ada dalam buah mengkudu. Suhu berpengaruh nyata terhadap kandungan vitamin C. Semakin tinggi suhu maka kandungan vitamin $\mathrm{C}$ semakin menurun [8]. Dibandingkan dengan The Natural Food Hub (2001), kadar vitamin C dari es rim noni $(36,89 \mathrm{mg} / 100 \mathrm{~g})$ hampir sama dengan kadar vitamin $\mathrm{C}$ buah jambu biji (37 $\mathrm{mg} / 100 \mathrm{~g}$ ) [9]. Berdasarkan kriteria dari National Institutes of Health (2011), ambang kadar kandungan vitamin $\mathrm{C}$ es krim noni ini sesuai untuk dikonsumsi oleh anak-anak sampai orang dewasa [10].

\section{Prospek Usaha Es Krim Noni}

Perhitungan harga pokok penjualan es krim noni ditentukan dengan HPP (harga pokok penjualan) sebesar Rp 1.660,- yang ditambah dengan mark up (keuntungan yang diperoleh) yaitu $80 \%$ Rp 1.328,- sehingga diperoleh hasil sebesar Rp 2.988,-. Berdasarkan hasil penjualan es krim noni (Gambar 3), diketahui bahwa nilai pendapatan, pengeluaran dan laba yang diperoleh mengalami kenaikan setelah dilakukan perbaikan mutu produk pada aspek rasa, warna dan penampilan. Hal ini dikarenakan konsumen lebih menyukai es krim yang mempunyai berbagai macam warna yang dapat meningkatkan daya tarik dari penampilan es krim noni tersebut.

Berdasarkan hasil yang diperoleh (Gambar 3) tingkat penjualan yang paling rendah terjadi pada minggu pertama yaitu terjual 12 cup es krim. Minggu kedua mengalami kenaikan 15 cup. Serta yang paling tinggi terjadi pada minggu keempat yang terjual 23 cup. 


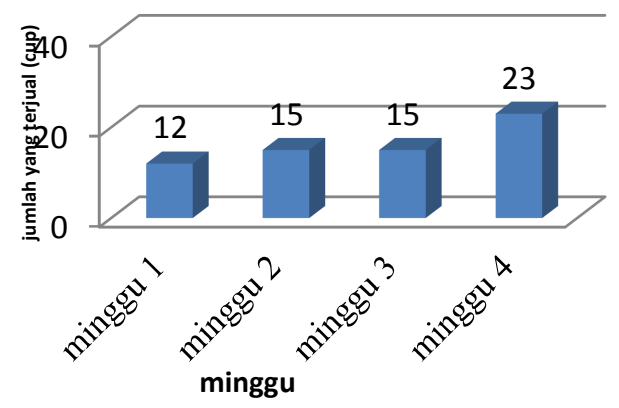

Gambar 3. Jumlah produk es krim noni yang terjual per cup dalam empat minggu

Perhitungan keuntungan total $(\pi)$ diperoleh hasil sebesar $\mathrm{Rp} 42.200,-$. Penjualan es krim noni memerlukan jangka waktu yaitu satu bulan untuk mengembalikan modal yang diinvestasikan jika diproduksi 4 adonan dengan harga jual minimum Rp 3.000,00 per wadah. Pada waktu yang sama total hasil penjualan yang harus diterima adalah $\mathrm{Rp} 1.460 .200,00$. Jika dilakukan penjualan pada perhitungan bulan selanjutnya, akan diperoleh laba minimum sebesar Rp 42.200,00.- satu bulan. Perhitungan analisis kelayakan usaha RCratio, diperoleh hasil rasio 1,27 (>1) yang menunjukkan bahwa usaha dari produk es krim noni ini layak untuk dilanjutkan serta dilakukan pengembangan dari produk tersebut. BEP (unit) minimal adalah sebesar 65 cup.

\section{KESIMPULAN}

Sebanyak 82,7 \% responden menyukai produk es krim Noni. Es krim noni mempunyai kadar lemak sebesar 6,54 \% lebih rendah dari standart SII sebesar $8 \%$. Kandungan vitamin $\mathrm{C}$ dari es krim noni $\mathrm{mg} / 100 \mathrm{~g}$. Tekstur dan rasa dari produk es krim noni yang paling banyak disukai responden adalah es krim dengan pencampuran $15 \%$ tekstur kasar buah mengkudu (69,9\%). Hasil penjualan es krim noni selama 1 (satu) bulan menunjukkan adanya keuntungan yang diperoleh sebesar $\mathrm{Rp}$ 42.200,-. Analisis kelayakan usaha es krim noni sebesar 1,27 $(>1)$ yang menunjukkan bahwa usaha dari produk es krim noni ini layak untuk dilanjutkan serta dilakukan pengembangan dari produk tersebut. Produksi es krim noni memiliki nilai BEP unit sebesar 65 cup.

\section{UCAPAN TERIMA KASIH}

Pada kesempatan ini, penulis ingin menyampaikan ucapan terima kasih kepada Dr. Serafinah Indriyani, M.Si dan Luchman Hakim,S.Si. M.Agr., Ph.D. selaku Dosen Penguji yang telah memberi saran yang bermanfaat demi perbaikan penyusunan skripsi. Widodo, SSi., Ph.D.Med.Sc, selaku Ketua Jurusan Biologi, Fakultas MIPA, Universitas Brawijaya.

\section{DAFTAR PUSTAKA}

[1] Sukarsono. 2003. Tumbuhan Untuk Pengobatan. UMM Press. Malang.

[2] Ariyanto. 2004.2 Morinda. http://www.herbal.ufl.edu. Diakses 2 Maret 2011.

[3] Kusumawati, F. 2008. Peningkatan Nilai Ekonomi Mengkudu (Morinda citrifolia L) Sebagai Upaya Peningkatan Apresiasi Terhadap Tanaman Obat Indonesia. Jurusan Biologi Fakultas Matematika dan Ilmu Pengetahuan Alam Universitas Brawijaya. Malang. Skripsi.

[4] Soekartawi. 1998. Agribisnis. PT. Raja Grafindo. Jakarta.

[5] Riyanto, B. 1990. Dasar-dasar Pembelanjaan Perusahaan. Yayasan Badan Penerbit Gadjah Mada. Yogyakarta.

[6] Waha, M.G. 2002. Sehat dengan Mengkudu. Ren Media. Jakarta.

[7] Padaga, M dan M.E. Sawitri. 2005. Membuat Es Krim Yang Sehat. Trubus Agrisarana. Surabaya.

[8] Rachmawati, Deviani \& Suriani. 2009. Pengaruh Suhu dan Penyimpanan terhadap Kadungan Vitamin C pada Cabe Rawit Putih (Capsicum frustenscens). Jurnal Biologi FMIPA Universitas Udayana. XIII.

[9] naturalhub. 2017. Natural food-Fruit Vitamin

Content. http://www.naturalhub.com/natu ral food guide fruit vitamin c.htm diakses 4 Desember 2017

[10] Institute of Medicine. 2000. Dietary Reference Intakes for Vitamin C, Vitamin E, Selenium, and Carotenoids. The National Academies Press. Washington, DC. 